\title{
Church History and Church Polity in the Faculty of Theology at the University of Pretoria
}

\section{Authors:}

Graham A. Duncan ${ }^{1}$

Johan van der Merwe ${ }^{1}$

Barry van $\mathrm{Wyk}^{1}$

\section{Affiliations:}

${ }^{1}$ Department of Church

History and Church

Politics, University of

Pretoria, South Africa

\section{Correspondence to:}

Graham Duncan

e-mail:

graham.duncan@up.ac.za

\section{Postal address:}

Faculty of Theology,

University of Pretoria,

Gauteng, 0002, South Africa

\section{Keywords:}

church history; church

polity; University of

Pretoria; Faculty of

Theology; Department of

Church History and Church

Politics

\section{Dates:}

Received: 27 Jan. 2009

Accepted: 12 Sept. 2009

Published: 17 Dec. 2009

How to cite this article:

Duncan, G.A., Van der

Merwe, J. \& Van Wyk,

B., 2009, 'Church History

and Church Polity in the

Faculty of Theology at the

University of Pretoria',

Verbum et Ecclesia 30(3), Art.

\#131, 6 pages. DOI: 10.4102/ ve.v30i3.131

\section{This article is available} at:

http://www.ve.org.za (c) 2009. The Authors.

Licensee: OpenJournals

Publishing. This work

is licensed under the

Creative Commons

Attribution License.

\begin{abstract}
Theology has been an integral part of the University of Pretoria since its inception and Church History has been taught since the establishment of the Faculty of Theology in 1917. At that time, the Presbyterian Church of South Africa and the Nederduitsch Hervormde Kerk van Afrika (NHK) were partners. The Presbyterian link with the Faculty ceased in 1933. From 1938 the Nederduits Gereformeerde Kerk (NGK) joined the NHK and this remained the situation until 2002 when the Uniting Presbyterian Church of Southern Africa re-established its links with the Faculty. At the present time, the Department of Church History and Church Polity is staffed by representatives of all three partner churches.
\end{abstract}

\section{INTRODUCTION}

In the Faculty of Theology at the University, the disciplines of Church History and Church Polity are taught within one department. The links between the subjects are obvious. However, too often, Church Polity is subsumed under Church History. Part of the reason for this is that, while Polity is a subject with its own integrity, it is for the most part and for good reason taught denominationally and at the higher levels of degree courses. In this article they will be treated as one subject.

Throughout the history of the Faculty, Church History has been presented by a series of distinguished scholars representing the partner churches, which have not only taught general Church History but have developed the subject within its South African context. They have been men who have been active in their own denominations and some of them have been active in international church bodies. This has enabled the teaching of the subject to be presented in its broader context, related to the ongoing life and witness of the world church.

\section{THE NEDERDUITSCH HERVORMDE KERK VAN AFRIKA (NHK)}

A historical survey of Church History in the NHK would be incomplete if the historical background was left out. Taking certain background events into account will explain why an own (Church-specific) theological training programme was considered of the utmost importance.

During the first quarter of the 19th century a sizable exodus of people from the Cape Colony occurred, caused by inhabitants who were dissatisfied with political developments. The exodus was criticised on the one hand by the Cape of Good Hope Punishment Act issued by the Cape Government and on the other hand by the Herderlike Skrywe of 1837 issued by the Church in the Cape Colony at the same time (Duvenage 1987:26; Engelbrecht 1953:43; Pont 1989:658).

Leaving the Cape Colony meant that these migrants no longer saw themselves as part of the church in which they were involved in the Cape. It is therefore no surprise that they founded new congregations, for example the congregation in Potchefstroom in 1842. Subsequently, the question arose as to where they would find ministers for the newly founded congregations arising out of the movement from the Cape. The first minister in the Transvaal was Rev. Dirk van der Hoff, who arrived in Potchefstroom from the Netherlands on 27 May 1853 (Engelbrecht 1953:83; Pont 1978:1978:250-254; Storm 1989:95).

The arrival of Rev. Dirk Postma, also from the Netherlands, resulted in a split in the Transvaal Church in 1859. This was caused mainly by different viewpoints, originating from the Netherlands, concerning the permissibility of singing hymns in church services (Pont 1978:268-271). Rev. P.A.C. van Heyningen also arrived in the Transvaal in 1859, again from the Netherlands. Van Heyningen is known for his contributions towards unity in the Church and State of the Transvaal (Dreyer 1999: 146-148). The third event, and this time of a decisively political nature, was the annexation by Theophilus Shepstone of the Transvaal in 1876 (Engelbrecht 1953:269), on behalf of the British Government. The resulting hostilities came to an end in February 1881 at Majuba (Dreyer 1999:158). The victory resulted in a feeling of unity in Transvaal Church circles (Dreyer 1999:160; Pont 1969:2009-2010). But when the two churches tried to manifest this unity in Church unification during 1885, it ended in an abortive Church unification between the NHK and the Cape-based NGK (Engelbrecht 1953:302-352; Pont 1978:293-295). Which was founded in the Transvaal in 1866 (Dreyer 1999:148; Engelbrecht 1953:216-217).

It was clear that arrangements needed to be made in the NHK to overcome the problems of providing in the ministry of the Church, at least for that part of the Church which did not enter into the union. Discussions on the establishment of the Church's own theological training commenced at the General Meeting of the Hervormde Kerk in 1890. At this time the Church had only one minister and had lost half its members as a result of the abortive unification (Oberholzer 1967:15).

In 1904 a significant event occurred when Prof. P.J. Muller, a minister in the Netherlands and professor at the University of Amsterdam since 1890, accepted a call to the NHK in South Africa. From 1906, he trained two ministers, both of whom were ordained in the Church (Oberholzer 1967:17). During the General Meeting of 1909 it was decided to establish a seminary and it is interesting to note that 
the curriculum provided for three years of training in Church History. However, the ideal situation was considered to be theological training at a university. This happened as a result of a resolution of the Curatorium on 25 January 1917 to establish a faculty of theology at the Transvaal University College (TUC), founded by the Union Government in 1908 (Oberholzer 1967:19).

The Board of the TUC appointed three lecturers, namely Prof. J.H.J.A. Greyvenstein (NHK) for New Testament, Dogmatics and Christian Ethics, Church History and Polity, Dr E. Macmillan (Presbyterian Church) for Old Testament, Philosophy of Religion and later Apologetics, and also Prof. A.C. Paterson for Old Testament. A five-year BA, BD course was established. It should be noted that, right from the beginning, Church History was considered of equal importance when considered in comparison with subjects like Old and New Testament ( $c f$. Oberholzer 1967:18,20; Pont 1992:258)

\section{Prof. S.P. Engelbrecht}

Church History gained full recognition when Prof. S.P. Engelbrecht was appointed as professor in 1921. He can justifiably be seen as the founder of scientific church history in South Africa as well as, subsequently, the father of the historic view of the NHK. His work was founded on scrupulous source and archival research which enabled him to give a responsible historic view of the past. It can be said that his theological position was not influenced by the ethical spokesmen in the Netherlands. According to his articles on Christian doctrine, it was obvious that his approach was confessionally based. It can be argued that Engelbrecht's value was not only in his historical precision but also in the fact that his theological judgement was based on Calvin and the historic confessions of the Church.

He was a good choice due to his versatility in theology, with special reference to historical material. He had a huge task to fulfill because the College did not have a well-stocked library or archive in those days. His interest in archival material and the gathering of relevant documents led to the establishment of the S.P. Engelbrecht Museum in the archive of the Hervormde Kerk (HK). One of his students described him by saying that his outstanding impression of Engelbrecht was his total involvement in the Church throughout its history, during times of glory and hardship. Although he also taught Ecclesiastical Law, his main area of interest was the history of the South African Church and in particular the position of the NHK. His interest in different aspects of history was also recognised by the government, resulting in his appointment to the Archive Board, as well as in the awarding of the Medal of Honour from the SA Academy for Science and Art in recognition of his contribution to the field of cultural history.

Engelbrecht commenced his work in 1921 and left a wellestablished Department of Church History in 1956, and this was recognised throughout the academic world (Oberholzer 1967:20-22; Pont 1992:261-270).

\section{Prof. A.D. Pont}

Pont paid tribute to his predecessors in his inaugural lecture held on 17 March 1957, but also indicated that new emphases were to be expected. Due to the deteriorating relations between the HK and the NHK, he incorporated the history of the NHK in general Church History, with special reference to the history of the Reformation. This also resulted in the changing of the Department's name from History of Christianity to Church History during 1973. This indicates Pont's view of history, according to which the Church is seen as a spiritual community and not just a spatial occurrence. The subject of Church History is then concerned with the history of a divine community and not just a chronicle of historic events without theological perspective. The past can be accepted as history if a relationship can be established with the present. History is therefore the past which can also be experienced in the present. For Pont, the achievement of absolute objectivity is impossible. The historian is expected to bring all the facts into discussion, stick to those facts and indicate the relationship of those facts to the past and present. The comprehension and evaluation of historical material is the full responsibility of the scholar and is therefore subjective. Pont accepted that objectivity depends on the approach and value judgement of the historian. Therefore the presuppositions of the historian are directly related to the significance attributed to historic facts.

Church History was viewed by Pont as the history of the Church from the time of Christ to the present, with the specific aim of calling on the Church in the present to take responsibility for the future. He worked with a linear view of history, pointing to a Church in transit from the time of its creation to the return of Christ. He considered Jesus Christ as the centre of Church History as well as the end and ultimate goal of history. He accepted, with Oscar Cullman, among others, a history of salvation perspective.

It is noteworthy that Pont also taught Ecclesiastical Law and that his most important research was done on this level. He started to explore the fundamental basis of the subject and indicated the important link between the doctrine of the Church and the managerial and disciplinary structuring of the Church. The critical question is: How will the fact that Jesus Christ is Lord of the Church and Ruler of the world come to its true fulfillment in the Church? He also indicated that there is a narrow relationship between Church History and Ecclesiastical Law. Actually, it is impossible to practise Ecclesiastical Law without Church History. It can safely be stated that Pont was the founder of the scientific study of Ecclesiastical Law in the HK. Prof. Pont's commitment to the Faculty as professor came to an end in 1992 with his retirement and appointment as professor emeritus (Botha 1967:33-34; Steenkamp 1992:275-288; Van Wyk 1992:534536)

\section{Prof. S.J. Botha}

Prof. S.J. Botha was appointed as successor to Prof. Pont in 1993. He will be remembered for his study, research and publications, through which he made a substantial contribution to the Biblical Reformation. For him, theology is a theology in the Church, which means for the Church. His contribution was twofold; on the one hand it was by way of his preaching and involvement in different commissions in the Church and, secondly, through his academic research and publications. Prof. Botha distinguished himself with his scrupulous research. According to him it was important that the history of the Church depended on facts and realities. He tried to create a true image of the past, because he was convinced that objective Church history was possible. Botha not only contributed through his research as such, but also in the reliability of his research work. He accepted the Church as a community of faithful people gathered by the Lord. Therefore his interest was not only focused on the historic side of the facts, but also on the history of doctrine among the people of the Church (Pretorius 2001:747-748).

It is clear from his list of publications (Breytenbach 2001:725730) that he also made a substantial contribution to the teaching and promotion of Ecclesiastical Law, with special reference to his involvement in the new Church Order accepted during 1997. His commitment finally ended on his retirement in 2002.

\section{Working Group for Church History and Polity}

The vacancy was not filled after Prof. Botha's retirement. This was part of a new dispensation in the Faculty of Theology, when one faculty was formed for the partner churches, the HK and the NGK. The Church, however, decided on a Working Group for Church History and Polity during 2003, consisting of all the promovendi. It was to accept responsibility for Church History (Dreyer 2003). This arrangement was maintained until 
Dr J.P. Labuschagne was appointed as a temporary and parttime lecturer in Church History and Polity during 2007. It is interesting to note that he emphasises the need for a paradigm shift for Church History as a history of theology, focusing on the theological debate in the different periods of the history of the Church (Labuschagne 2008).

\section{NEDERDUITSE GEREFORMEERDE KERK (NGK)}

For the NGK, the story of the Department of Church History and Church Polity officially begins on 16 March 1938 with the appointment of the first four professors of Theology in the newly formed Faculty of Theology section B, the second Faculty of Theology for the Dutch Reformed Church (NGK) (Deo Gloria 1962:25). The Hervormde Kerk's part of the Faculty was now known as section A

The creation of the Faculty of Theology in Pretoria was the realisation of a dream for the NGK which started much earlier. As far back as 1916, two lecturers of the Transvaal University College, later to be known as the University of Pretoria, who were delegates to the Transvaal Synod of the Dutch Reformed Church, asked the synod to consider the training of ministers in the Transvaal. Nothing came of their request at that time. At the next synod in 1919 a letter from the University, asking for the appointment of two professors in Theology, was presented (Van der Watt 1988:6). In 1922, the Rev. Paul Nel pleaded with the synod to seriously consider establishing a Faculty of Theology in the Transvaal. Nel met resistance from within the Church when the synod of the then Dutch Reformed Church in the Transvaal declared in 1934:

dat dit noodlottig sal wees vir die eenheid van ons kerk en vir die bevordering van die Christendom in ons Vaderland indien ' $n$ Teologiese Fakulteit in Transvaal vir ons kerk opgerig sal word.

(Die Kerkbode 6 Junie 1934: 1044)

It would take another four years of intense discussions to realise the dream of a faculty of theology for the Dutch Reformed Church in the northern part of the country. The dream became a reality with the appointment of G.M. Pellissier as professor in Dogmatics, E.P. Groenewald as professor in New Testament, J.H. Kritzinger as professor in Old Testament and D.J. Keet as professor in Church History (Van der Watt 1988:13).

The appointment of Daniël Johannes Keet marked the official beginning of the Department of Church History and Church Polity in the Faculty of Theology Section B at the University of Pretoria.

\section{Staff who made a difference}

In the 70 years of the existence of the Department of Church History and Church Polity, different staff members played a major role in teaching and forming young theologians for the Dutch Reformed Church. They also had a huge influence on Church and society.

\section{D.J. Keet: Founder}

Prof. D.J. Keet laid the foundation in the early years of the Department's history. Being the first professor, he was entrusted with the design of the initial curriculum. Keet served in the Department of Church History until his retirement in 1953. In 1955 he was appointed as archivist of the Transvaal Synod of The Dutch Reformed Church, a position he held until his death on 20 April 1962 (Hofmeyr 1971:43). Keet's greatest influence was in the way in which he conducted his work as a lecturer. The high esteem in which he was held by colleagues at the university is proof of this. After his retirement in 1952, he was retained by the Senate of the University until the end of 1953 . He received the status of professor emeritus in June 1953 (Rautenbach 1960:173)

\section{B.J. Marais: Prophet against apartheid}

In 1953 Barend Jacobus Marais was appointed as the second professor in the Department. After studying at Stellenbosch he went to Princeton Theological Seminary (USA) where he obtained his MTh degree in 1936. After returning to South Africa, he was ordained as a minister in the Dutch Reformed Church, where he served as a student minister and later a minister of the DRC Congregation Pretoria East until 1952. He retired in 1974 (Van der Watt 1988:85).

Marais will be remembered not only as a great lecturer, but as one of the greatest critics of the Dutch Reformed Church's policy on race relations. In 1952, even before becoming professor in Church History, he published the book: Die Kleur krisis in die weste. It was later translated as: Colour, unsolved problem of the west (Borchardt 1988:49). Marais was known as a critic of the policy of segregation, which the Dutch Reformed Church founded on scripture. His book caused an upheaval in Church and society as it openly criticised the policy of the newly elected National Party government that came into power in 1948. Marais' critique of the policy of separate development and segregation was met with sharp resistance in Church and government circles.

He was also influential in the international arena. From 19531954 he was a member of the International Study Commission of the World Council of Churches on 'The Church and Race'. Marais was one of six speakers at the 1954 Evanston meeting of the World Council of Churches. This led to an official inquiry by the Curatorium after they received a letter from the 'Ring' of Langlaagte (Borchardt 1988:49). Since Marais was there in his personal capacity, nothing further came of the matter. Marais took part in the writing of the book, Vertraagde Aksie, which was published in 1960. During the synod meeting of the Transvaal Synod of the Dutch Reformed Church in 1961, all the writers of the book were severely reprimanded for the viewpoints they expressed. He retired in 1974 as persona non grata to many in the Dutch Reformed Church.

Prof. Ben Marais spent his life fighting against the injustice of the policy of segregation, later known as apartheid. Recognition of his contribution finally came in 1994 at the General Synod of the Dutch Reformed Church. This was only months after the first multi-racial general election in South Africa, which saw the African National Congress forming the new government. The newly elected State President was invited to address the Synod. Mr Nelson Mandela addressed the meeting on 13 October 1994 and challenged the meeting to give recognition to prophets from the past, people like Prof. Ben Marais, who warned the Church against the evils of apartheid (Handelinge 1994:536).

The next day, the synod took a decision to recognise its guilt in the past of unbrotherly conduct towards people who stood up against the tyranny of apartheid. Ben Marais, who was already ill, attended the meeting. After the decision was read to him, the synod sang Ps 134:4 to him. The wheel had turned full circle. Ben Marais was welcomed back as a hero.

P.B. van der Watt: Academic, writer and Church leader P.B. (Flip) van der Watt succeeded Ben Marais. Born in Theunissen in the FreeState, Van der Wattstudied atStellenbosch before going to Amsterdam in 1966 where he studied at the Vrije Universiteit until 1967. After returning to South Africa, he received his DTh degree at the University of Stellenbosch. Ordained as a minister, he served in several congregations before being appointed as Senior Lecturer at the University of Stellenbosch in 1971. In 1975 he was appointed as head of the Department of Church History at the University of Pretoria (Van der Watt 1988:85).

A brilliant lecturer, Van der Watt not only quickly made his mark in the academic environment, but also distinguished himself as Church leader. As an academic he wrote 471 articles in newspapers and contemporary magazines and published 38 books on Church History (Van der Watt 2008). His most important contribution was recording the history of the Dutch Reformed Church from 1652 to 1975. This monumental work, 
published in four parts, is still the most complete work on the history of the Dutch Reformed Church. In recognition of his work, he was awarded the South African Academy for Science and Arts Totius Prize for Theology in 1988. Van der Watt was appointed as Dean of the Faculty of Theology in 1987 and served until 1989.

As a Church leader Van der Watt excelled in his work on different Church commissions. In 1983 he became Assessor of the Synod of the Northern Transvaal. He served in the position until 1987 when he became Moderator of the Synod, a post he held until 1991. During this time he also served on the Commission of the General Synod of the Dutch Reformed Church (Van der Watt 2008).

Van der Watt was not only an academic and Church leader, he also had a keen interest in sport and student affairs. Being a staunch rugby supporter, he was elected President of the Rugby Club of the University of Pretoria in 1991. He also served as a committee member of the Northern Transvaal Rugby Union. To his students, Van der Watt and the Blue Bulls rugby team were synonymous. His interest in student affairs was recognised by the University of Pretoria when he was appointed Student Dean in 1989, a post he held until his retirement in 2001 (Van der Watt 2008).

Although retired, Van der Watt was tasked by management of the University of Pretoria to compile a coffee-table book to be published in 2008, celebrating the Centenary of the University of Pretoria. Only history will reveal what Prof. P.B. van der Watt really meant to Church and society. As Head of the Department of Church History and Church Polity, he was an academic, writer and Church leader par excellence.

\section{C.F.A. Borchardt: A witness to society}

Carl Frederick August Borchardt was appointed professor in Church History in 1976. He partnered Prof. van der Watt in the Department.

Borchardt started his career in Theology in 1952. He received his BA degree in 1954, his BD in 1957 and his MA in 1960. He also studied at the Rijksuniversitiet in Leiden in the Netherlands where he received his DTh degree in 1966. After serving in different congregations, Borchardt was appointed as Senior Lecturer at the University of South Africa in 1970 (Van der Watt 1988:85). He became head of the Department in 1989 when he succeeded Prof. van der Watt.

Prof. Borchardt had a keen interest in Church and society. The injustices in society brought about by the political system of apartheid bothered him so much that he became part of the so called 'Reformation Day Witness', published in die Kerkbode on the 31 October 1980 (Die Kerkbode 5 November 1980:605). It brought him into conflict with the Curatorium of the Theological Faculty and the Church leadership.

The Witness was written by eight theologians, three from the Theological Faculty of Pretoria, namely Borchardt, J.A. Heyns and A.B. du Toit, and four from the Theological Faculty at Stellenbosch, namely J.H. Combrink, W.P. Esterhuyse, W.D. Jonker, B.A. Muller and H.W. Rossouw. The eight stated their concern about the inability of the Dutch Reformed Church to perform her prophetic calling in South Africa, especially regarding the injustices in society (Borchardt 1988:605). It did not take long before Borchardt and the co-signatories of the Witness were on the proverbial red carpet. The Curatorium met on 19 and 20 November 1980. In a strongly worded letter to all the staff of the Faculty of Theology, they requested lecturers at the faculty not to make any declarations that could lead to mistrust in the Church, and not to make such declarations in an organised way. They also asked why the Witness was published on Reformed Day, if nothing sinister was meant by it (Venter 1980). This was not the end of the matter. Early in 1981 all the ministers of the
Dutch Reformed Church in the Transvaal were summoned to a secret meeting at Hartebeespoort Dam where the Church leadership again reprimanded the professors. Borchardt's being part of the Reformed Day Witness illustrated how seriously he felt about Church and society.

Carl Borchardt had to retire due to ill health at the end of 1994 (Rautenbach 1960:116).

\section{J.W. Hofmeyr: The Department goes international}

Johannes Wynand Hofmeyr received his BA, BA (Hons) and BD degrees at the University of Pretoria before going to Kampen in the Netherlands for further studies. He received his ThD at Kampen in 1975. After ministering in the Dutch Reformed congregation Brenthurst, he was appointed as Senior Lecturer at the University of South Africa in 1983 and promoted to professor in 1987. In 1990 he was appointed as professor at the University of Pretoria (Jaarboek 2008:364). He became head of the Department in 1995.

Hofmeyr published several articles and books. In an interview with him in 2008, he mentioned that his most prominent books were Die Nederlandse Nadere Reformasie en sy invloed op twee kontinente; A History of Christianity in South Africa (co-authored by Prof. G.J. Pillay of Unisa in 1991); and African Christianity: An African Story, as co-editor with Prof. O.U. Kalu in 2005.

It also became clear in this interview that although all his predecessors had international connections, it was Hofmeyr who really took the Department into the international academic arena. Being the author of several articles and books, his forte was international networking. He made contact with renowned international scholars like Mark Noll of the University of Notre Dame, USA; J. Carpenter of Calvin College, USA, and Hans van Oort of Utrecht in the Netherlands. He was also appointed on the Accrediting and Evaluation Committee of the Belgian Government concerning standards for theological faculties in Belgium.

Under his leadership, one of the largest international conferences in Church History on the African Continent was organised in 2001 with the University of Cambridge's Faculty of Divinity and supported by the Pew Charitable Trusts. The Conference took place from 3 to 7 July and was held at the Hammanskraal Campus of the University of Pretoria. The main theme was 'Interpreting Contemporary Christianity: Global Processes and Local Identities'. The line-up of main speakers included Akintunde Akinade from Highpoint University in North Carolina in the USA, Edith Blumhofer from Wheaton College in Illinois in the USA, Joel Carpenter from Calvin College in Michigan in the USA and Silas Wu from Boston College in the USA. Delegates from all over the world attended, which made it the most inclusive congress ever held on Church History in South Africa.

Hofmeyr also had a vision for co-operation in Africa. Time and energy was invested in an all-African project with the aim of introducing African Christianity to the world. He was invited to Justo Mwale Theological College in Lusaka, Zambia, as guest lecturer. As a direct result of this cooperation, African Christianity: An African Story was published in 2005 (Kalu 2005:1)

After the retirement of Prof. Borchardt in 1994, the situation in the Department changed when it was decided that the second post in the Department would not be filled. Drs H.S. Grobler (1995-1997), P.R. du Toit (1998-2008) and J.M. van der Merwe (1997-2007) were employed as part-time lecturers to assist Hofmeyr. Dr E. Buchner also later assisted as a lecturer.

Prof. Hofmeyr retired in 2007, leaving behind a legacy of international contacts and a strong academic network in Africa.

J.M. van der Merwe: Building on a legacy

After the retirement of Prof. J.W. Hofmeyr, Johan Matthys van der 
Merwe was appointed in January 2008. Van der Merwe received his BD degree in 1988 and his DD under the promotorship of Prof. P.B. van der Watt in 1990. Being a minister in the Dutch Reformed congregation, Pretoria-Garsfontein, he lectured part time in the Department from 1997. Van der Merwe is author of several articles and co-writer of the book Moeisame pad na vernuwing, which was published in 2002 . With his appointment a new future beckons - to build on the legacy left by his extraordinary predecessors. The legacy forms the foundation of a launch pad to propel the Department into a future with new challenges. Building the Department by promoting Church History and Church Polity as subjects through dedicated teaching, doing relevant research and serving the community will be the main focus areas.

The history of the Department of Church History and Church Polity Section B is a history of dedicated lecturers who served the subject, the University of Pretoria and the Church for 70 years. From the pioneering work of Prof. D.J. Keet to the prophetic voice of Prof. B.J. Marais, the inspirational leadership and academic skill of Prof. P.B. van der Watt, the call to witness of Prof. C.F. Borchardt, the building of international networks and reaching out to Africa by Prof. J.W. Hofmeyr, all played a major role in establishing a department that has made its mark not only in South Africa but also in the international academic arena. Since 2000 the Department has become part of a multi-church faculty, partnering with the NHK and the Uniting Presbyterian Church in Southern Africa in one Department of Church History and Church Polity. This new road brings new challenges to the current lecturers and students.

\section{THE UNITING PRESBYTERIAN CHURCH IN SOUTHERN AFRICA}

Although Presbyterians of the Presbyterian Church of South Africa (PCSA) were involved in the Faculty of Theology at the University of Pretoria from its inception, the only lecturer nominated by the PCSA, Rev. Prof. E Macmillan, taught History and Philosophy of Religion. Macmillan also taught Hebrew and his theology was assessed as 'geheel modern' (NHK 1919) by some. Macmillan refused to take a confessional approach in his teaching. This could have been done in a denominational school, which his own denomination has constantly eschewed as a means of preparing its candidates for the ministry. He rather preferred the descriptive method. His approach was governed by a strict integrity:

And what of the Bible in the light of modern criticism - do our young people know anything of the work that is being done to recover the true inwardness of the beginnings of Christianity? - a work only comparable with that of Luther and the Reformation, who were themselves a return to the religious experience of the early Church.

(Moderatorial Address, 1923, in Lang 1945:58)

The Presbyterian connection with the university came to an end in 1933 when Macmillan resigned due to the pressure of other commitments. During this period no Presbyterian students had actually studied at Pretoria.

This connection was only re-established in 2002, as a result of a decision taken by the recently (1999) united Uniting Presbyterian Church in Southern Africa, to centralise its ministerial training programme in a few institutions, the main centre being the University of Pretoria. Rev. Dr Graham Duncan, who had taught Practical Theology and Church History at the Federal Theological Seminary of Southern Africa (1982-1987) and Church History more recently at the University of Fort Hare (1998-2001), was transferred to the Department of Church History and Church Polity in the Faculty of Theology at the University of Pretoria as Senior Lecturer to assistant professor J.W. Hofmeyr.

Duncan had obtained his BEd and BD (Hons) degrees in Aberdeen in Scotland, and his MTh and DTh in Missiology, specialising in
SA mission history, at the University of South Africa. He was promoted to associate professor in 2005 and became acting head of department in 2007 on Prof. Hofmeyr's retirement. In 2007 he was awarded a PhD in Church History at UP in the field of contemporary mission history. His main interest lies in South African mission history related to the English-speaking churches and particularly theological education.

A further innovation occurred in 2008 with the appointment of Prof. Hans van Oort of Utrecht-Nijmegen in the Netherlands as honorary professor in the Department. Prof. van Oort brings distinctive scholarship in the field of Early Church History and Patristics, being an internationally renowned expert on Augustine of Hippo.

\section{CONCLUSION}

Currently, at the beginning of the second century of the University of Pretoria, the Department of Church History and Church Polity has never been better staffed. There are teaching representatives from all the partner churches of the Faculty of Theology and the Department has the services of an internationally renowned Patristics scholar. Apart from tending to the needs of the partner churches as well as an increasing number of black students in the Faculty, the Department currently offers postgraduate supervision to students throughout Africa and as far afield as Korea and the USA. Developing emphases include a renewed stress on Church History as the history of theology, ecumenical Church history and Church history in the African context. Developing trends within the University of Pretoria and its Faculty of Theology suggest that the future will see a greater trend towards intra- and interdisciplinary co-operation. Church History by its very nature lends itself to working in a relational manner with other disciplines. It never did operate as an isolated discipline and certainly cannot do so in the future. It has a strong affinity to and interdependence with the humanities and social sciences in particular. Consequently, the Department is well placed as the process of restructuring programmes and preparing new curricula is embarked upon.

\section{REFERENCES}

Borchardt, C.F.A., 1988, 'Faculteit en Kerk in Deo Gloria! Teologiese Fakulteit, 1938-1988' Die Kerkbode, 5 November, p. 605.

Botha, S.J., 1967, 'Na vyftig jaar', 1930-1967. Gedenkalbum, Teologiese Faculteit 1917-1967:24-36.

Breytenbach, A.P.B., 2001, 'SJ Botha - huldigingsbundel by geleentheid van aanvaarding vanemeritaat: Huldingswoord', HTS Teologiese/Theological Studies 57 (3\&4), 721-731.

Dreyer, W.A., 1999, Nederduitsch Hervormde Kerk van Afrika - die eerste 250 jaar: 1652-1902, Kital, Pretoria.

Dreyer, W.A., 2003, Letter to members of the Workgroup of the Reformed Theological College, November.

Dutch Reformed Church, 1994, Handelinge van die Negende Vergadering van die Algemene Sinode van die Ned Geref Kerk, Pretoria.

Duvenage, G.D.J., 1987, Die Groot Trek, die eerste drie jaar. Die manifes, Afrikaner Volkswag, Pretoria.

Engelbrecht, S.P., 1953, Geskiedenis van die Nederduitsch Hervormde Kerk van Afrika, HAUM, Pretoria.

Hofmeyr, J.W., 1971, Geskiedenis van die Teologiese Fakulteit van die Ned Geref Kerk aan die Universiteit van Pretoria vanaf 19381970, BD thesis, Faculty of Theology, University of Pretoria.

Hofmeyr, J.W., 2002, Ad Destinatum IV 1993-2000. Historical developments and events at the University of Pretoria, University of Pretoria, Pretoria.

Jaarboek van die Ned Geref Kerk, 2008, Bybelmedia, Wellington.

Labuschagne, J.P., 2008, 'n Nuwe paradigma vir kerkgeskiedenis, Opening address to the Reformed Theological College, 31 January. 
Lang, J. (ed.), 1945, 'Happy Seeker, Happy Finder': A memoir of Dr Ebenezer Macmillan of St Andrews Church, Pretoria, with some sermons and addresses, Van Schaik, Pretoria.

Nederduitsch Hervormde Kerk, 1919, Notules van die Kuratorium vir die Teologiese Opleiding van die Nederduitsch Hervormde Kerk, NHKA, Pretoria.

Oberholzer, J.P., 1967, 'Na vyftig jaar, 1917-1930', Gedenkalbum Teologiese Fakulteit, 15-23.

Pont, A.D., 1969, 'Kerk en volk', HTS Teologiese/Theological Studies 25 (3\&4), 202-218.

Pont, A.D., 1978, Kerkgeskiedenis. 'n Oorsig van die Algemene Kerkgeskiedenis van die Nederduitsch Hervormde Kerk van Afrika, HAUM, Pretoria.

Pont, A.D., 1989, 'Die Groot Trek en die kerk', HTS Teologiese Studies/Theological Studies 45(3), 655-670.

Pont, A.D., 1992, 'Kerkgeskiedenis in ons teologiese opleiding, 1917-1956', HTS Teologiese/Theological Studies 48(1\&2), 253 272.

Pretorius, S.P., 2001, 'Prof. S.J. Botha: 'n waardering van sy lewe en werk', HTS Teologiese Studies/Theological Studies 57(3\&4), 732-758.
Rautenbach, C.H., 1960, Ad Destinatum - Gedenkboek van die Universitiet van Pretoria. (1910-1960),p16, Voortrekkerpers, Johannesburg.

Steenkamp, J.J., 1992, 'Die teologiese gerigtheid van die Departement Kerkgeskiedenis, 1957-1992', HTS Teologiese/ Theological Studies 48(1\&2), 273-291.

Storm, J.M.G., 1989, Die Voortrekkerkerk, 1836-1853, Kital, Pretoria.

Van der Watt, P.B., (red), 1988, Deo Gloria! Teologiese Fakulteit 1938-1988, NGKB, Pretoria.

Van der Watt, P.B., 2007, Curriculum vitae, Pretoria.

Van Wyk, D.J.C., 1992, 'Prof. Dr A.D. Pont: 'n waardering van sy lewe en werk', HTS Teologiese/theological Studies 48(3\&4), 515-574.

Venter, G.J.C., 1980, Letter from Curatorium to lecturers of the Faculty. 